\title{
Visceral adiposity, insulin resistance and cancer risk
}

\author{
Claire L Donohoe, Suzanne L Doyle and John V Reynolds ${ }^{*}$
}

\begin{abstract}
Background: There is a well established link between obesity and cancer. Emerging research is characterising this relationship further and delineating the specific role of excess visceral adiposity, as opposed to simple obesity, in promoting tumorigenesis. This review summarises the evidence from an epidemiological and pathophysiological perspective.
\end{abstract}

Methods: Relevant medical literature was identified from searches of PubMed and references cited in appropriate articles identified. Selection of articles was based on peer review, journal and relevance.

Results: Numerous epidemiological studies consistently identify increased risk of developing carcinoma in the obese. Adipose tissue, particularly viscerally located fat, is metabolically active and exerts systemic endocrine effects. Putative pathophysiological mechanisms linking obesity and carcinogenesis include the paracrine effects of adipose tissue and systemic alterations associated with obesity. Systemic changes in the obese state include chronic inflammation and alterations in adipokines and sex steroids. Insulin and the insulin-like growth factor axis influence tumorigenesis and also have a complex relationship with adiposity. There is evidence to suggest that insulin and the IGF axis play an important role in mediating obesity associated malignancy.

Conclusions: There is much evidence to support a role for obesity in cancer progression, however further research is warranted to determine the specific effect of excess visceral adipose tissue on tumorigenesis. Investigation of the potential mechanisms underpinning the association, including the role of insulin and the IGF axis, will improve understanding of the obesity and cancer link and may uncover targets for intervention.

\section{Methodology}

Relevant medical literature was identified from searches of PubMed and references cited in appropriate articles identified. Search terms used included: obesity, overweight, cancer, adipose tissue, inflammation, insulin, metabolic syndrome, adipokines and sex steroids. More detailed search terms were used following identification of relevant mechanisms and to identify epidemiological studies. All meta-analyses addressing cancer incidence with respect to body mass index were identified by PubMed searches. Meta-analyses of cohort or nested case control studies only were included. When available, meta-analyses were preferentially cited as epidemiological evidence. Selection of other articles was based on peer review, journal and relevance. Where possible,

\footnotetext{
* Correspondence: reynoljv@tcd.ie

Department of Surgery, Trinity Centre for Health Sciences, Trinity College Dublin/St James' Hospital, Dublin 8, Ireland
}

review articles from high impact factor peer-reviewed journals were cited.

\section{Introduction}

The World Health Organisation defines obesity as an abnormal or excessive fat accumulation in adipose tissue, to the extent that health is impaired. The classification of obesity for epidemiological purposes defines overweight as body mass index (BMI) greater than 25 $\mathrm{kg} / \mathrm{m}^{2}$ and obesity as BMI greater than $30 \mathrm{~kg} / \mathrm{m}^{2}[1]$ (Table 1). The obese state is increasingly more prevalent in Western society and in some countries is the most prevalent body composition [2,3].

Adipose tissue is principally deposited in two compartments - subcutaneously and centrally (Figure 1). It is thought that centrally deposited, or visceral, fat is more metabolically active than peripheral subcutaneous fat [4-6]. Visceral adipose tissue is largely comprised of omental adipose tissue but also includes other intra-

\section{() Biomed Central}


Table 1 Body Mass Index as a predictor of risk to health, WHO (2004)

\begin{tabular}{ll}
\hline Classification & $\mathbf{B M I}\left(\mathbf{k g} / \mathbf{m}^{2}\right)$ \\
\hline Underweight & $<18.50$ \\
Normal Weight & $18.50-24.99$ \\
Overweight/Pre-Obese & $25.00-29.99$ \\
Obese Class I & $30.00-34.99$ \\
Obese Class II & $35.00-39.99$ \\
Obese Class III & $\geq 40.00$
\end{tabular}

BMI, body mass index

abdominal fat sources such as mesenteric fat. Visceral adipose tissue secretes a number of adipokines and cytokines leading to a proinflammatory, procoagulant and insulin resistant state collectively known as the metabolic syndrome [7]. The importance of adipose tissue location in terms of dysmetabolism risk is evident as central obesity is more strongly associated with increased risk of insulin resistance, the metabolic syndrome and cardiovascular diseases than BMI alone [8]. For any given amount of total body fat, the subgroup of individuals with excess visceral fat (versus subcutaneous fat) is at higher risk of developing insulin resistance [9] and the features of the metabolic syndrome [10].

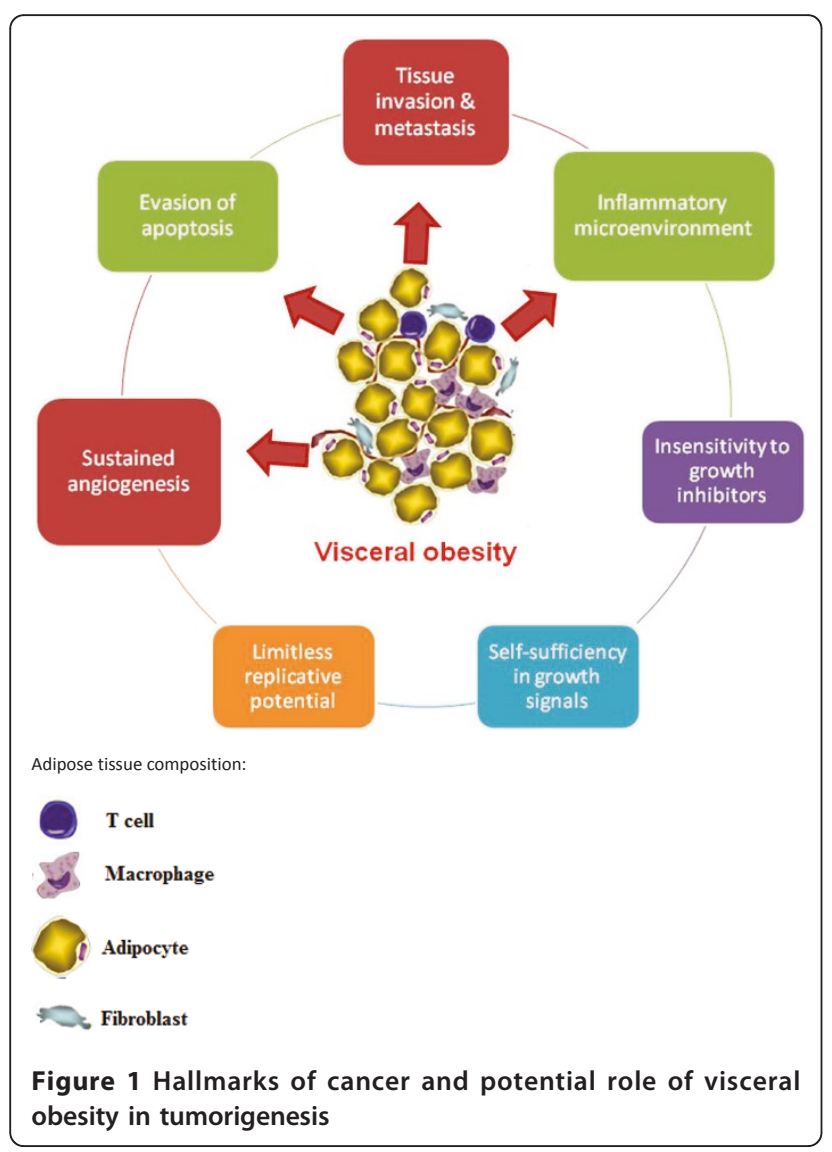

Visceral fat remains more strongly associated with an adverse metabolic risk profile even after accounting for the contribution of other standard anthropometric indices [11]. These systemic effects exerted by visceral adiposity are putatively involved in cancer biology [12] and are the focus of much research.

\section{Measuring Visceral Adiposity}

Commonly used BMI cut-off values to diagnose obesity have high specificity, but low sensitivity to identify adiposity, as they fail to identify those with excess body fat [13]. Waist circumference (WC) has been shown to be an accurate predictor of visceral fat, either alone or in combination with BMI [14]. WC directly reflects total abdominal fat mass $[15,16]$ and gender and ethnic specific cut-offs can be used as reliable proxy values to predict an increased risk of the metabolic disease However, WC fails to quantify the visceral and subcutaneous fat compartments individually and there are no clearly defined cut-off values for an increase in cancer risk. Computed tomography (CT) imaging is the gold standard for the measurement of adiposity, since this allows for direct quantification of adipose tissue and can distinguish between visceral and superficial fat compartments [17]. In terms of cardiovascular risk, peripheral fat accumulation (as measured by leg subcutaneous fat deposition) may be protective [11]. Therefore, waist:hip ratio (WHR) measurements may be more relevant in determining CVD risk than WC alone. Whether this is the case for cancer risk is not yet known.

\section{Gender influence on visceral adiposity}

Gender influences fat distribution, with women having a greater amount of peripherally located subcutaneous fat and men having a greater amount of centrally located visceral fat [8]. Men store about $20-30 \%$ of their total body fat in the visceral compartment irrespective of their obesity status [18]. Women do not accumulate significant quantities of visceral fat until a moderate level of obesity is reached and non-obese women have very small amounts of visceral fat [19]. On average, men have twice as much visceral fat as women and demonstrate a high prevalence of the obesity-related metabolic diseases and the metabolic syndrome [20,21].

The cause of this gender difference is uncertain but may be related to the higher amount of hepatic free fatty acid delivery derived from lipolysis from visceral fat that has been observed in women compared to men [22]. In addition, oestrogen may be a key regulator in mediating differences in adipose tissue distribution between men and women [8]. Pre-menopause, women have higher levels of subcutaneous adiposity and there is a lower incidence of obesity associated dysmetabolism. However, after menopause, circulating levels of 
oestrogen fall and adipose tissue distribution becomes more "male-like" with increased amounts of visceral adiposity and a subsequent increased risk of obesityrelated metabolic disorders [8].

\section{Obesity and cancer: epidemiology evidence}

Epidemiological studies provide convincing evidence of an association between obesity and cancer development at numerous sites: oesophagus (adenocarcinoma), pancreas, colorectum, breast (postmenopausal), endometrium and kidney [23]. The largest meta-analysis to date includes 282,000 patients from prospective observational studies with over 133 million person-years of follow-up [24]. This shows that high body mass index is associated with an increased incidence of many types of cancer. The association is modest with risk estimates of 1.1 to 1.6 per $5 \mathrm{~kg} / \mathrm{m}^{2}$ incremental increase in BMI. This $5 \mathrm{~kg} /$ $\mathrm{m}^{2}$ increase in BMI corresponds to $15 \mathrm{~kg}$ weight gain in men and $13 \mathrm{~kg}$ in women with an average BMI of 23 $\mathrm{kg} / \mathrm{m}^{2}$. The associations between obesity and cancer are sex and site specific but broadly consistent across geographic populations [24]. Emerging evidence suggests that weight loss following bariatric surgery leads to a reduction in cancer incidence [25]. The association also fulfils many of Hill's postulates [26] (plausible biological mechanisms, consistent associations, sufficient latency period, reversibility) indicating that the obesity is likely to be causal.

Furthermore, a prospective study of 900,000 adults in the United States reported that obesity could account for $14 \%$ of all deaths from cancer in men and $20 \%$ in women [27]. Those with a BMI greater than $40 \mathrm{~kg} / \mathrm{m}^{2}$ had a death rate $52 \%$ higher in men and $62 \%$ higher in women when compared to those of normal weight. This indicates that obesity may also affect outcomes following cancer diagnosis and this finding is supported by other studies which control for increased peri-operative mortality rates amongst the obese [28-31].

There appears to a sex differential with respect to risk of cancer development with men having a higher risk of developing cancer at increased BMI than women $[24,32]$. This may be due to the differing hormonal milieu in females or it may reflect the fact that BMI poorly reflects central adiposity in females. Since females generally only deposit central adipose tissue once total fat volumes are raised, overweight BMIs do not correspond with visceral fat volume in females as they do in males which may account for the differences in cancer risk seen when BMI is used to determine obesity status.

In studies that use measures of visceral adiposity such as WC or VFA, visceral adiposity is associated with increased risk of cancer development [32-34]; is a stronger predictor of cancer risk than BMI [32] and the cancer risk is similar in males and females [32,33]. Further, larger studies using measures of visceral adiposity across cancer sites are awaited in order to clarify whether there is a clear differential effect of visceral versus subcutaneous obesity.

Visceral adiposity (and not subcutaneous adiposity) is associated with development of features of the metabolic syndrome (taken as a proxy measure of a dysmetabolic profile in viscerally obese patients)[35]. Most of the components of the syndrome, alone [36,37] or in combination [38-40], have been individually link with cancer development at various subsites. A prospective international population-based study of 580,000 people (Me-Can Study) is underway to identify whether the metabolic syndrome is independently associated with cancer development [41]. Initial findings suggest that a combination of components of the metabolic syndrome is associated with risk of colorectal cancer development (Men: RR: 1.25 (95\% CI; 1.18-1.32; Women: RR 1.14 (95\% CI; $1.02-$ 1.18)[42], endometrial cancer ( $R R$ 1.37, 1.28-1.46) [43], bladder cancer in men (RR: 1.1, 1.01-1.18) [44] and pancreatic cancer in women (RR,1.58; 1.34-1.87)[45].

\section{Mechanisms underlying obesity and tumorigenesis}

Long thought of as inert, adipose tissue, particularly visceral fat [46], is an important metabolic tissue which secretes factors systemically that alter the immunological, metabolic and endocrine milieu and promote insulin resistance [4]. The obese state may be thought of as a pro-tumorigenic environment which can act to facilitate tumour development by promotion of the acquisition of some of the hallmarks properties that characterise cancerous lesions (Figure 1)[47,48].

\section{Paracrine mechanisms}

Adipose tissue may act in both a paracrine and systemic manner. At a local level, adipose tissue is involved in a number of mechanisms which may promote tumor development (Figure 2). Obese mice have reduced levels of oxygen within their epididymal adipose tissue [49]. The tumor microenvironment in solid tumors is often characterised by low oxygen tensions and hypoxia within the peri-tumoral fat may promote tumor-site hypoxia. Hypoxia upregulates the hypoxic-inducible

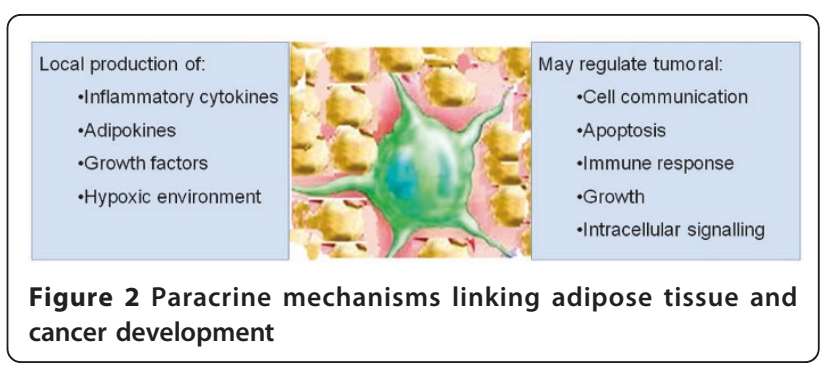


factor (HIF-1 $\alpha$ ) which can lead to altered expression in over 60 target genes involved in angiogenesis, glycolysis, cell proliferation and apoptosis, leading to cellular adaptation to low oxygen conditions [50]. Hypoxia has been associated with metastasis and poor prognosis [51] and also induces pro-angiogeneic and inflammatory cytokine secretion [52-54].

Inflammatory cytokines produced in adipose tissue can upregulate nuclear factor $-\kappa \mathrm{B}(\mathrm{NF} \kappa \mathrm{B})$ which leads to an increase in nitric oxide (NO), a substrate for reactive oxygen species (ROS). Cytokines and ROS can contribute to insulin resistance and the resultant excess circulating glucose, free fatty acids and insulin can further induce inflammation [55]. The key inflammatory pathways $\mathrm{NF} \kappa \mathrm{B}$ and STAT3 are activated by adipose tissue products leading to transcription of genes which mediate proliferation, invasion, angiogenesis, survival and metastasis [56].

The observation that epithelial tumor cell growth is enhanced by injection into fat pads rather than subcutaneously [57] supports the hypothesis that chemokine production within the adipose tissue provides conditions which enhance tumor cell growth. A proteomic study of mammary fat revealed the production of a wide variety of proteins involved in diverse processes such as cell communication, growth, immune response, apoptosis and numerous signalling molecules including hormones, cytokines and growth factors [58].

While fat which surrounds individual organs may act in a paracrine manner to influence tumor development or progression, this mechanism is less fully investigated and most research efforts have concentrated on systemic alterations in obesity and how these may influence cancer development and progression. Adipokine production and inflammatory alterations in the obese state described in detail hereafter may act to influence tumorigenesis in either a systemic or paracrine manner or a combination of both.

\section{Systemic mechanisms}

Systemic alterations in obesity include chronic systemic inflammation, increased adipokine production and an altered immunological status (Figure 3). Additionally,

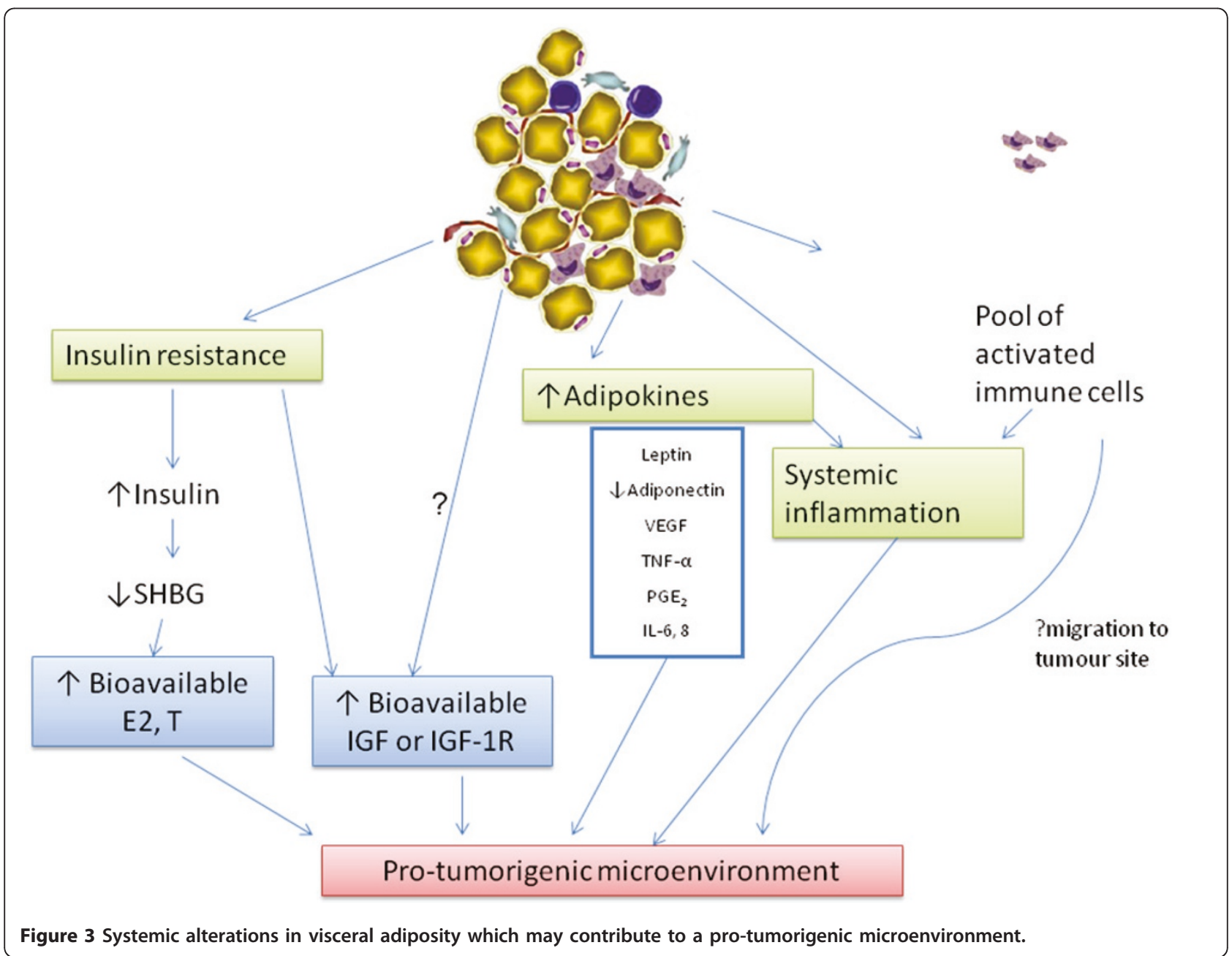


there are associated changes in the sex hormone profile. Insulin resistance develops as a consequence of visceral adiposity and there is a rise in insulin production, which may be associated with activation of the insulin-like growth factor (IGF) system. All of these changes which occur in tandem with the development of obesity have the ability to interact with each other. It is this altered systemic milieu which is thought to fuel cancer development and progression.

\section{Chronic inflammation and adipokines}

Excess adipose tissue results in elevated levels of proinflammatory adipokines, resulting in an imbalance between increased inflammatory stimuli and decreased anti-inflammatory mechanism leading to persistent lowgrade inflammation $[46,59,60]$. The level of adipokine production from adipose tissue is strongly influenced by immune cell populations present in adipose tissue [4,61-63]. Adipose tissue in obese people is infiltrated with macrophages and the number of macrophages correlates with the degree of adiposity [64]. Peripheral monocytes are recruited by monocyte chemoattractant protein (MCP)-1 and TNF- $\alpha$, and can differentiate into activated macrophages [65]. Pre-adipocytes also have the ability to differentiate into macrophages [61]. The products of activated macrophages can impact on adipocyte function and are postulated to be involved in altering adipose tissue glucose handling and thus contribute to insulin resistance $[66,67]$. Research has shown that coculture of adipocytes with macrophage-conditioned media causes increased adipokine and inflammatory cytokine production by adipocytes [68], further supporting this hypothesis.

Insulin can modulate adipokine production and interacts with two of the most abundant adipokines: leptin and adiponectin. Insulin is a positive regulator of leptin and increases its gene expression to suppress appetite [69]. Adiponectin acts as an insulin sensitising agent [69]. In addition to modulation of insulin sensitivity, these adipokines can directly affect tumor cells [70]. Adiponectin is anti-tumor: it increases apoptosis[71], inhibits proliferation, inflammation and angiogenesis [72] and can prevent the interaction of growth factors with their receptors [73]. There is a consistent inverse relationship with cancer incidence and circulating adiponectin [74]. The pro-tumor effects of leptin are the direct opposite of those of adiponectin [74], although the epidemiological association between circulating levels and cancer risk is less consistent [75]. Circulating levels of leptin positively correlate and adiponectin levels negatively correlate with all measures of obesity (BMI, WC and visceral fat area)[76-78].

Thus altered adipokine production by adipose tissue, and in particular inflammed visceral adipose tissue, may influence the tumor microenvironment. Obese rat models have increased inflammatory transcription factor expression (TNF $\alpha$ and $\mathrm{NF} \kappa \mathrm{B}$ ) in their tumors [79]. Furthermore, there is emerging evidence that adipose stromal cells may be a source of stromal cells in tumor microenvironments. Early adipocyte precursor cells can differentiate into stromal cells [80]. In animal models of obesity, adipose stromal cells and adipose endothelial cells from inflamed visceral adipose tissue migrate to tumor sites [81]. Stromal cells in the tumor microenvironment promote angiogenesis and support tumor progression [82]. There is also evidence that visceral adiposity can influence a patient's treatment outcome, with a study demonstrating increased visceral fat area to be an independent predictor of outcome after first-line bevacizumab treatment in colorectal cancer [83]. This finding indicates that angiogenic factors produced by visceral fat may influence tumor progression and response to chemotherapy and is mirrored in animal models as adiponectin, which is reduced in visceral obesity, inhibits tumor growth by reduced neovascularisation[72]. The mechanism(s) for this resistance may uncover important information on how obesity influences the tumor microenvironment.

\section{Sex hormones}

Epidemiological studies have suggested a difference in the influence of obesity on cancer development between men and women [27]. While some studies are inconsistent, the risk of colorectal cancer in post-menopausal women does not seem to be related or only weakly associated with obesity $[84,85]$. It has been hypothesised that different distributions of adipose tissue between men and women accounts for the difference [86]. Whether this is mediated by affecting circulating sex hormone levels is not fully understood. Adiposity is inversely related to testosterone concentration in men but positively related in women [87]. Excess adipose tissue leads to increased conversion of androgenic precursors to oestradiol by increased aromatase activity [88]. In endometrial cancer, oestradiol increases cell proliferation via inducing a local increase in IGF-1 [89].

Different influences of circulating oestrogen levels may influence cancer development [90]. Chronic hyperinsulinaemia may promote tumorigenesis in oestrogen-sensitive tissues as it reduces circulating sex-hormone binding globulin and thus increases bioavailable oestrogen [27,91-93]. The association between obesity and postmenopausal breast cancer risk is accounted for by the increased serum oestradiol levels as obesity increases [94] and since in females, most fat deposition occurs peripherally, this fat area may be of more relevance to endometrial and post-menopausal breast cancer risk.

\section{Insulin resistance}

Levels of adipose tissue affect the body's handling of glucose [95]. Adipokines are thought to be involved in 
the pathogenesis of insulin resistance $[96,97]$ and as previously mentioned insulin can modulate adipokine activity. High concentration of cytokines produced by adipose tissue, such as TNF- $\alpha$, IL-6, IL-1 $\beta$, and low concentrations of adiponectin, have deleterious effects on glucose homeostasis leading to chronic hyperinsulinaemia and insulin resistance in Type 2 Diabetes Mellitus $[98,99]$.

Insulin resistance is an adaptive response to raised circulating free fatty acids (FFAs) and thus is related to the extent of visceral adipose tissue deposits [100]. Raised FFAs shift metabolism of liver, muscle and other tissues towards lipid deposition and oxidation and away from gluconeogenesis and glycolysis. Insulin secretion rises to compensate for the decreased capacity to handle glucose. Despite this there is a decreased expression of insulin-receptor levels and reduced intracellular insulin signalling in response to insulin receptor binding [101]. Subcutaneous adipose tissue takes up free fatty acids and stores the excess calories more readily than visceral adipose tissue [102]. Rates of lipolysis are higher in visceral adipocytes than superificial [11], due to the antilipolytic effect of insulin being increased in subcutaneous adipose tissue [46]. Therefore, the risk of developing insulin resistance is related to the size of visceral fat deposits.

Several epidemiological studies have shown that insulin resistance status, characterised by hyperinsulinaemia, is associated with an increased risk for a number of malignancies, including carcinomas of the breast, prostate and colon[103-106]. Per $1 \mathrm{mmol} / \mathrm{l}$ increment in glucose from data of the MeCan study cohort has revealed an increase risk of incident cancer in men (RR 1.05, 1.01-1.1) and women (1.11, 1.05-1.16) and a further increased RR for fatal cancer (Men: 1.15, 1.07-1.22; Women: 1.21,1.11-1.33)[103].

\section{Insulin and cancer}

Insulin can act as a mitogen and has been associated with several cancers[107]. The tumorigenic effects of insulin could be directly mediated by insulin receptors in the pre-neoplastic target cells, or might be due to related changes in endogenous hormone metabolism, secondary to hyperinsulinaemia [100]. Epidemiological studies are hampered by the heterogeneity of diabetic patients with respect to their degree of glycaemic control which will influence their circulating insulin levels and hence making correlations with cancer development difficult.

Epidemiological studies have shown that serum Cpeptide, as a proxy measure of insulin release, is associated with increased risk of cancer of the colorectum, post-menopausal breast, pancreas and endometrium [108] and that type 2 diabetes is associated, independent of obesity, with breast, pancreas, kidney, endometrial, colorectal and bladder cancer [109]. Cohort studies have demonstrated increase risk of colorectal cancer in those with insulin resistance, $[38,40,110]$ the metabolic syndrome [111] and type 2 diabetics [112]. The risk of cancer-related mortality is increased in those with high insulin levels or insulin resistance and cancers of the breast [113], prostate [114] and colorectum[115]. Colorectal cancer incidence is higher in Type 2 diabetics treated with insulin [116].

In vitro studies support epidemiological data in that insulin increases the neoplastic proliferation of cell lines at both physiological and pharmacological doses [117] and the insulin receptor is commonly expressed in human neoplasms. Under investigation at present is whether there are differential effects downstream signalling effects in normal or transformed epithelial cells compared to insulin-responsive tissues (such as fat, liver and muscle) with receptor activation resulting in cell survival and proliferation rather than altered energy metabolism [118]

\section{Insulin-like growth factors, obesity and cancer}

The interaction between insulin, body fat and the IGF axis is less well understood. It has been proposed that the IGF system mediates the effect of hyperinsulinaemia and is more relevant to cancer development and progression than insulin (Figure 2). The insulin-like growth factors are involved in enhancement of cell proliferation, differentiation and apoptosis and have been implicated in tumorigenesis $[119,120]$. Levels of IGF are influenced by circulating insulin levels which alter the level of IGF binding protein 1 and 2 (IGFBP1 \& 2) increasing bioavailability of IGF [121].Waist circumference and waist: hip ratio are inversely associated with IGFBP1 levels in healthy females[122]. The collective findings from a number of studies show that IGFBP1 \& 2 is inversely associated with body fat and insulin levels and that there does not appear to be a direct correlation between total IGF1 levels and body fat or insulin [123]. Rather, there is a non-linear relationship between BMI and total IGF-1 levels (with the highest levels in those with a BMI up to $27 \mathrm{~kg} / \mathrm{m}^{2}$ [124]) However, the relationship between measures of visceral adiposity and IGF-1 levels is unclear. In addition, there is a debate as what constitutes bioavailable IGF-1 (total or free fractions) and whether IGFBPs and their relationship to total IGF-1 levels should be taken into account.

\section{The IGF axis}

The IGF axis is a multifunctional system with a variety of molecular and biological effects. To date, 15 molecular functions and 29 biological processes have been linked to the IGF-1R in the gene ontology database 
(http://www.geneontology.org). Proteins from the axis are ubiquitously expressed but at different levels in different tissues and with varying roles in each tissue. The IGF axis can have auto-, para- and endocrine effects. The main biological processes that the IGF axis is involved with can be summarised as: control of normal growth $[118,125]$ (and perhaps lifespan [126]); maintenance of tissue homeostasis [127] and a differentiated phenotype [128]; alteration in the balance of proliferation and apoptosis [129]; angiogenesis, cell adhesion, migration and wound healing [129].

IGF-1 and IGF- 2 are bound by 6 high affinity binding proteins (IGFBP1-6) and other low affinity binding proteins (IGFBP-related proteins). IGFBP1-5 have higher affinities for IGF-1, whereas IGFBP6 has a higher affinity for IGF-2 [130]. IGFBPs stabilise and prolong the halflife of IGFs and by binding IGFs prevent their binding to receptors. IGFs are released from IGFBPs by dissociation or protease-mediated IGFBP cleavage [130]. Thus IGFBPs alter the bioactivity of IGF and in some circumstances act to increase the bioactivity of IGF. This is thought to occur by IGFBPs binding IGFs in proximity to their receptor and acting to concentrate IGFs at receptors and through the slow release of the growth factors can influence the duration of signalling via the receptor [130]. Another hypothesis is that IGFBP2 binds an integrin-linked kinase to increase IGF bioactivity [118]. The tumor suppressor p53, vitamin D, anti-oestrogens, retinoids and TGF $\beta$ reduce the bioactivity of IGFs by increasing secretion of IGFBPs [130]. IGFBPs may also have independent effects on proliferation, adhesion and motility. Certain IGFBPs modulate Wnt signalling which is involved in differentiation and this modulation is influenced by local concentrations of IGF ligands [131]. Thus the IGF system is highly regulated via a dynamic system of binding proteins which influence growth factor stability, receptor binding and duration of receptor activation.

IGF-1R is a transmembrane heterotetrameric protein encoded by the IGF-1R gene located on chromosome $15 q 25-q 26$. IGF-1R is composed of two $\alpha$ and two $\beta$ subunits. Due to structural homology with the insulin receptor it can heterodimerize with it. The IGF-1R receptor binds (ranking from high to low affinity): IGF1, IGF-2 and insulin[132]. IGF-1R is a tyrosine kinase receptor which initiates intracellular signalling upon receptor activation by autophosphorylation and stimulation of tyrosine kinase activity, leading to recruitment and phosphorylation of the insulin-receptor substrate-1 (IRS-1). These receptor substrates activate two main signalling pathways: PI3K-AKT and RAS-Raf-MAPK which have multiple effects on gene regulation and protein expression, activation and translocation [129]. The availability, location and ratios of receptor substrates influence cellular responses to receptor activation and may also alter the balance of IGF signalling and insulin signalling when heterodimers of IGF/insulinR are bound. Several mechanisms of crosstalk which influence IGF-1R receptor function have been describes including heterodimers with EGFR[133] and SOCS interactions influencing the Jak-Stat pathway[134].

\section{IGF axis and cancer}

Two of the hallmarks of cancer [47] are limitless replication and evasion from apoptosis (Figure 1). The IGF axis is a central regulator of growth and survival. It has been found that IGF-1R plays a role in the establishment and maintenance of cellular transformation [135]. IGF-1R or its ligands are often over-expressed in human tumors [136,137] and its action protects against apoptosis and favours invasion and metastasis [119,120,129]. Activation of IGF-1R can promote cell migration and the redistribution of E-cadherin and $\alpha$ - and $\beta$ - catenins from adherens junctions into the cytoplasm [138]. IGF-1 also modulates the activities of integrin-coupled proteins (FAK, p130, Cas and paxillin) through dephosphorylation [139].

The IGF-1R is commonly expressed by neoplastic cell lines and human cancers and on circulating tumor cells $[136,137,140]$. However, gene amplification is not commonly associated with protein overexpression or ligandindependent activation [118]. The IGF-1R has been found to be essential for oncogenic transformation in some cellular systems. Mouse fibroblasts cannot be transformed by the oncogenes: SV40 T antigen, papillomavirus E5 and Ras overexpression if they lack the IGF$1 R$ [135]. Stable (constitutive) activation of IGF-1R is insufficient to cause mammary epithelial cell transformation in mouse models [141].

Many cell lines are mitogenically responsive to physiological concentrations of IGFs [132]. Increased proliferation in response to raised IGF levels may fuel the development of early cancers. Using prostate cancer as a model, there appears to be an increased likelihood of progression to clinically detectable malignancy in patients with higher IGF-1 levels such that baseline IGF-1 level predicts progression to prostate cancer more accurately than prostate-specific antigen in screened populations $[142,143]$. In vivo animal models using natural occurring mutations associated with low IGF levels $[144,145]$ or genetic manipulations to influence ligand levels [146,147], result in variability of neoplastic growth related to IGF activity. Animal models have shown decreased tumor growth after IGF1R inactivation and with decreased circulating or tissue levels of IGF1 $[121,148]$.

Studies of patients with acromegaly [149] or Laron dwarfisim [150] have been used as proxies to identify 
cancer risk in relation to IGF-1 excess or deficiency. They provide circumstantial evidence that increased IGF-1 levels are associated with cancer. Other forms of circumstantial evidence include the observation that height and birth weight, which is related to the concentration of IGF-1 in the umbilical cord, are related to the risk of some cancers [151-153]. Mammographic breast density, which is a strong risk factor for breast cancer is related to the level of circulating IGF-1 genes [154,155] and to polymorphisms in IGF-related genes [154,156].

Population based studies have provided evidence that relate circulating ligand levels as well as polymorphic variation of relevant genes to cancer risk and prognosis. Prospective epidemiologic studies provide evidence of a relationship between circulating IGF-1 and the risk of developing prostate, breast, colorectal and other cancers [142,143,157-161]. Individuals at the high end of the normal range of serum IGF-1 have more than double the risk of a subsequent cancer. Variability between studies, particularly regarding the potential reciprocal relationship between IGFBP3 and IGF-1 levels may be accounted for by technical challenges in measuring IGF and uncharacterised factors that modify IGF-1 levels including age and diurnal variation. Studies of single nucleotide polymorphisms in the IGF-1 axis genes indicate a potential relationship between SNPs and circulating levels [154,162] but increased risk of cancer development with IGF SNPs is unclear[163]. Studies report polymorphic variants associated with colorectal [164], oesophageal [165], ovarian [166] and non-small cell lung cancer [167] but not with breast or prostate cancer [168]. These studies require confirmation in other populations.

\section{IGF axis and obesity}

Alterations in the IGF axis have been implicated in malignancies that are also associated with obesity, suggesting the IGF axis may play a mechanistic role in linking obesity and cancer. There is a paucity of studies examining the influence of obesity on IGF-1R in tumor tissue. A study in breast cancer demonstrated that increasing BMI was positively associated with increased IGF-1R expression in both normal mammary gland tissue and breast cancer tissue [169]. Furthermore research has found that IGF-1R expression is significantly higher in the colorectal neoplasms of individuals with metabolic syndrome than in the lesions of individuals without the syndrome [170]. The findings of these studies suggest that the molecular consequence of obesity is the increased expression of IGF-1R in both normal and malignant tissue.

As mentioned previously, elevated levels of free IGF-1 have been reported in obese individuals and are believed to be a consequence of hyperinsulinaemia inhibiting production of IGFBP-1 and -2[123,171]. The chronic systemic inflammation associated with obesity is believed to fuel tumor development and progression, and IGF-1 may mediate obesity-associated inflammation via its effects on immune cells, including macrophages. Studies have shown IGF-1 can lead to macrophage migration and invasion, and also increased macrophage production of proinflammatory cytokines [172,173]. In addition, recent research has supported a functional role for IGF-1 in obesity associated inflammation and tumorigenesis. In a murine model of obesity and chronic IGF-1 gene deficiency, diet-induced obese mice demonstrated increased local tumor growth and metastases compared to lean controls, but this was not seen in IGF-1 gene deficient mice. In addition, the expression of inflammatory cytokines and cell adhesion molecules was upregulated in obese compared to lean mice, but chronic IGF-1 deficiency was associated with a reduction in these indicators [174]. Hence it is possible that in obesity IGF-1 can affect tumor development both directly, by stimulating tumor growth and indirectly, by creating a microenvironment that is permissive for tumor growth.

\section{Summary and future directions}

Obesity is likely to a causal factor for a number of common cancers, however, the mechanisms underpinning this association are not fully understood. Current hypotheses include the development of chronic inflammation with increased adiposity, which alters immune, sex steroid and adipokine function. In turn, alterations in insulin sensitivity and the IGF axis occur. Any or all of these systems act in concert to promote the development and progression of cancer at a cellular level. How these systemic conditions interact at the tumor site and whether their influence is site-specific, is a complex question. There has been little investigation of paracrine models of adipose tissue function in the obese state.

Some of the systemic changes associated with obesity are enhanced in the group of patients with visceral adiposity. Similar to the increased risk associated with central obesity and development of cardiovascular and metabolic disease, visceral fat may be more relevant to cancer development. Studies which measure central obesity as well as BMI may clarify whether total fat or visceral fat distribution is most relevant.

Future research using accurate definitions of obesity status are important in order to accurately determine the risk associated with obesity and whether the risk is specific to visceral fat.

\section{Acknowledgements}

This work is supported by a research scholarship from the Irish Cancer Society and the Irish Research Council for Science, Engineering and Technology. 


\section{Authors' contributions}

CLD and SLD drafted the manuscript, JVR conceived of the review and revised the manuscript. All authors have read and approved the final manuscript.

\section{Competing interests}

The authors declare that they have no competing interests.

Received: 8 December 2010 Accepted: 22 June 2011 Published: 22 June 2011

\section{References}

1. Obesity: preventing and managing the global epidemic. Report of a WHO consultation. World Health Organ Tech Rep Ser 2000, 894:i-xii, 1-253.

2. Flegal KM, Carroll MD, Ogden CL, Curtin LR: Prevalence and Trends in Obesity Among US Adults, 1999-2008. JAMA: The Journal of the American Medical Association 2010, 303:235-241.

3. Berghofer A, Pischon T, Reinhold T, Apovian C, Sharma A, Willich S: Obesity prevalence from a European perspective: a systematic review. BMC Public Health 2008, 8:200

4. Kershaw EE, Flier JS: Adipose tissue as an endocrine organ. J Clin Endocrinol Metab 2004, 89:2548-2556.

5. Vohl MC, Sladek R, Robitaille J, Gurd S, Marceau P, Richard D, Hudson TJ, Tchernof A: A survey of genes differentially expressed in subcutaneous and visceral adipose tissue in men. Obes Res 2004, 12:1217-1222.

6. Galic S, Oakhill JS, Steinberg GR: Adipose tissue as an endocrine organ Mol Cell Endocrinol 2010, 316:129-139.

7. Despres J-P, Lemieux I: Abdominal obesity and metabolic syndrome. Nature 2006, 444:881-887.

8. Nedungadi TP, Clegg DJ: Sexual dimorphism in body fat distribution and risk for cardiovascular diseases. J Cardiovasc Transl Res 2009, 2:321-327.

9. Kissebah AH, Vydelingum N, Murray R, Evans DJ, Kalkhoff RK, Adams PW: Relation of Body Fat Distribution to Metabolic Complications of Obesity. J Clin Endocrinol Metab 1982, 54:254-260.

10. Despres JP, Moorjani S, Lupien PJ, Tremblay A, Nadeau A, Bouchard C: Regional distribution of body fat, plasma lipoproteins, and cardiovascular disease. Arteriosclerosis 1990, 10:497-511.

11. Snijder MB, Dam RMV, Visser M, Seidell JC: What aspects of body fat are particularly hazardous and how do we measure them? International Journal of Epidemiology 2006, 35:83-92.

12. van Kruijsdijk RCM, van der Wall E, Visseren FLJ: Obesity and Cancer: The Role of Dysfunctional Adipose Tissue. Cancer Epidemiology Biomarkers \& Prevention 2009, 18:2569-2578.

13. Okorodudu DO, Jumean MF, Montori VH, Romero-Corral A, Somers VK, Erwin PJ, Lopez-Jimenez F: Diagnostic performance of body mass index to identify obesity as defined by body adiposity: a systemic review and meta-analysis. Internation Journal of Obesity 2010, 34:791-799.

14. Zhu S, Heshka S, Wang Z, Shen W, Allison DB, Ross R, Heymsfield S: Combination of BMl and waist circumference for identifying cardiovascular risk factors in whites. Obesity Research 2004, 12:633-645.

15. Kashihara H, Lee J, Kawakubo K, Tamura M, Akabayashi A: Criteria of Waist Circumference According to Computed Tomography-Measured Visceral Fat Area and the Clustering of Cardiovascular Risk Factors. Circ J 2009, 73:1881-1886.

16. Lemieux S, Prud'homme D, Bouchard C, Tremblav A, Després J-P: A single threshold value of waist girth identifies normal weight and overweight subjects with excess visceral adipose tissue. Am J Clin Nutr 1996, 64:685-693.

17. Balentine CJ, Marshall C, Robinson C, Wilks J, Anaya D, Albo D, Berger DH: Validating Quantitative Obesity Measurements in Colorectal Cancer Patients. Journal of Surgical Research 2010, 5:1-5.

18. Björntorp P: Metabolic difference between visceral fat and subcutaneous abdominal fat. Diabetes Metab 2000, 26:13-12.

19. Björntorp P: Abdominal obesity and the metabolic syndrome. Ann Med 1992, 24:465-468.

20. Ford ES, Li C, Zhao G, Pearson WS, Mokdad AH: Prevalence of the metabolic syndrome among U.S. adolescents using the definition from the International Diabetes Federation. Diabetes Care 2008, 31:587-589.

21. Oka R, Kobayashi J, Yagi K, Tanii H, Miyamoto S, Asano A, Hagishita T, Mori M, Moriuchi T, Kobayashi M, et al: Reassessment of the cutoff values of waist circumference and visceral fat area for identifying Japanese subjects at risk for the metabolic syndrome. Diabetes Res Clin Pract 2008, 79:474-481.

22. Fox CS, Massaro JM, Hoffmann U, Pou KM, Maurovich-Horvat P, Liu CY, Ramachandran S, Vasan S, Murabito JM, Meigs JB, et al: Abdominal Visceral and Subcutaneous Adipose Tissue Compartments:Association With Metabolic Risk Factors in the Framingham Heart Study. Circulation 2007 116:39-48

23. Fund WCR: Food, nutrition, physical activity and the prevention of cancer: a global perspective. Book Food, nutrition, physical activity and the prevention of cancer: a global perspective. 2 edition. City: American Institute for Cancer Research; 2007.

24. Renehan AG, Tyson M, Egger M, Heller RF, Zwahlen M: Body-mass index and incidence of cancer: a systematic review and meta-analysis of prospective observational studies. Lancet 2008, 371:569-578.

25. Sjostrom L, Gummesson A, Sjostrom CD, Narbro K, Peltonen M, Wedel H, Bengtsson C, Bouchard C, Carlsson B, Dahlgren S, et al: Effects of bariatric surgery on cancer incidence in obese patients in Sweden (Swedish Obese Subjects Study): a prospective, controlled intervention trial. Lancet Oncol 2009, 10:653-662.

26. Hill AB: The Environment and Disease: Association or Causation? Proc $R$ Soc Med 1965, 58:295-300.

27. Calle EE, Rodriguez C, Walker-Thurmond K, Thun MJ: Overweight, obesity, and mortality from cancer in a prospectively studied cohort of U.S. adults. N Engl J Med 2003, 348:1625-1638.

28. Li D, Morris JS, Liu J, Hassan MM, Day RS, Bondy ML, Abbruzzese JL: Body mass index and risk, age of onset, and survival in patients with pancreatic cancer. JAMA 2009, 301:2553-2562.

29. Meyerhardt JA, Catalano PJ, Haller DG, Mayer RJ, Benson AB, Macdonald JS, Fuchs CS: Influence of body mass index on outcomes and treatmentrelated toxicity in patients with colon carcinoma. Cancer 2003, 98:484-495.

30. Haydon AM, Macinnis RJ, English DR, Giles GG: Effect of physical activity and body size on survival after diagnosis with colorectal cancer. Gut 2006, 55:62-67.

31. Dignam JJ, Polite BN, Yothers G, Raich P, Colangelo L, O'Connell MJ, Wolmark N: Body mass index and outcomes in patients who receive adjuvant chemotherapy for colon cancer. J Natl Cancer Inst 2006, 98:1647-1654.

32. Moore LL, Bradlee ML, Singer MR, Splansky GL, Proctor MH, Ellison RC, Kreger BE: BMI and waist circumference as predictors of lifetime colon cancer risk in Framingham Study adults. Int J Obes Relat Metab Disord 2004, 28:559-567.

33. Wang Y, Jacobs EJ, Patel AV, Rodriguez C, McCullough ML, Thun MJ, Calle EE: A prospective study of waist circumference and body mass index in relation to colorectal cancer incidence. Cancer Causes Control 2008, 19:783-792.

34. Steffen $A$, Schulze MB, Pischon T, Dietrich T, Molina E, Chirlaque MD, Barricarte A, Amiano P, Quiros JR, Tumino R, et al: Anthropometry and esophageal cancer risk in the European prospective investigation into cancer and nutrition. Cancer Epidemiol Biomarkers Prev 2009, 18:2079-2089.

35. Donohoe CL, Pidgeon GP, Lysaght J, Reynolds JV: Obesity and gastrointestinal cancer. British Journal of Surgery 2010, 97:628-642.

36. Cowey S, Hardy RW: The metabolic syndrome: A high-risk state for cancer? Am J Pathol 2006, 169:1505-1522.

37. Giovannucci E: Metabolic syndrome, hyperinsulinemia, and colon cancer: a review. Am J Clin Nutr 2007, 86:5836-842.

38. Colangelo LA, Gapstur SM, Gann PH, Dyer AR, Liu K: Colorectal cancer mortality and factors related to the insulin resistance syndrome. Cancer Epidemiol Biomarkers Prev 2002, 11:385-391.

39. Bowers K, Albanes D, Limburg P, Pietinen P, Taylor PR, Virtamo J, Stolzenberg-Solomon R: A prospective study of anthropometric and clinical measurements associated with insulin resistance syndrome and colorectal cancer in male smokers. Am J Epidemiol 2006, 164:652-664.

40. Trevisan M, Liu J, Muti P, Misciagna G, Menotti A, Fucci F: Markers of insulin resistance and colorectal cancer mortality. Cancer Epidemiol Biomarkers Prev 2001, 10:937-941.

41. Stocks T, Borena W, Strohmaier S, Biørge T, Manjer J, Engeland A, Johansen D, Selmer R, Hallmans G, Rapp K, et al: Cohort Profile: The Metabolic syndrome and Cancer project (Me-Can). International Journal of Epidemiology 2010, 39:660-667. 
42. Stocks T, Lukanova A, Bjørge T, Ulmer H, Manjer J, Almquist M, Concin H, Engeland A, Hallmans $G$, Nagel $G$, et al: Metabolic factors and the risk of colorectal cancer in 580,000 men and women in the metabolic syndrome and cancer project (Me-Can). Cancer 2010.

43. Bjørge T, Stocks T, Lukanova A, Tretli S, Selmer R, Manjer J, Rapp K, Ulmer H, Almquist M, Concin $\mathrm{H}$, et al: Metabolic Syndrome and Endometrial Carcinoma. American Journal of Epidemiology 2010, 171:892-902.

44. Häggström C, Stocks T, Rapp K, Bjørge T, Lindkvist B, Concin H, Engeland A, Manjer J, Ulmer H, Selmer R, et al: Metabolic syndrome and risk of bladder cancer: prospective cohort study in the metabolic syndrome and cancer project (Me-Can). International Journal of Cancer 2010.

45. Johansen $D$, Stocks $T$, Jonsson $H$, Lindkvist B, Björge $T$, Concin $H$, Almquist M, Häggström C, Engeland A, Ulmer H, et al: Metabolic Factors and the Risk of Pancreatic Cancer: A Prospective Analysis of almost 580,000 Men and Women in the Metabolic Syndrome and Cancer Project. Cancer Epidemiology Biomarkers \& Prevention 2010, 19:2307-2317.

46. Wajchenberg BL: Subcutaneous and visceral adipose tissue: their relation to the metabolic syndrome. Endocr Rev 2000, 21:697-738.

47. Hanahan D, Weinberg RA: The hallmarks of cancer. Cell 2000, 100:57-70.

48. Mantovani A: Cancer: Inflaming metastasis. Nature 2009, 457:36-37.

49. Ye J, Gao Z, Yin J, He Q: Hypoxia is a potential risk factor for chronic inflammation and adiponectin reduction in adipose tissue of ob/ob and dietary obese mice. Am J Physiol Endocrinol Metab 2007, 293:E1118-1128.

50. Vaupel P: The Role of Hypoxia-Induced Factors in Tumor Progression. Oncologist 2004, 9:10-17.

51. Zhong H, De Marzo AM, Laughner E, Lim M, Hilton DA, Zagzag D, Buechler $P$, Isaacs WB, Semenza GL, Simons JW: Overexpression of Hypoxia-inducible Factor 1a in Common Human Cancers and Their Metastases. Cancer Research 1999, 59:5830-5835.

52. Trayhurn P, Wood IS: Adipokines: inflammation and the pleiotropic role of white adipose tissue. Br J Nutr 2004, 92:347-355.

53. Feldser D, Agani F, lyer NV, Pak B, Ferreira G, Semenza GL: Reciprocal positive regulation of hypoxia-inducible factor 1alpha and insulin-like growth factor 2. Cancer Res 1999, 59:3915-3918.

54. Fukuda R, Hirota K, Fan F, Jung YD, Ellis LM, Semenza GL: Insulin-like growth factor 1 induces hypoxia-inducible factor 1-mediated vascular endothelial growth factor expression, which is dependent on MAP kinase and phosphatidylinositol 3-kinase signaling in colon cancer cells. J Biol Chem 2002, 277:38205-38211.

55. Sonnenberg GE, Krakower GR, Kissebah AH: A novel pathway to the manifestations of metabolic syndrome. Obes Res 2004, 12:180-186.

56. Aggarwal BB, Vijayalekshmi RV, Sung B: Targeting inflammatory pathways for prevention and therapy of cancer: short-term friend, long-term foe. Clin Cancer Res 2009, 15:425-430.

57. Elliott BE, Tam SP, Dexter D, Chen ZQ: Capacity of adipose tissue to promote growth and metastasis of a murine mammary carcinoma: effect of estrogen and progesterone. Int J Cancer 1992, 51:416-424.

58. Celis JE, Moreira JM, Cabezon T, Gromov P, Friis E, Rank F, Gromova I: Identification of extracellular and intracellular signaling components of the mammary adipose tissue and its interstitial fluid in high risk breast cancer patients: toward dissecting the molecular circuitry of epithelialadipocyte stromal cell interactions. Mol Cell Proteomics 2005, 4:492-522.

59. Esposito K, Giugliano D: The metabolic syndrome and inflammation: association or causation? Nutr Metab Cardiovasc Dis 2004, 14:228-232.

60. Das UN: Is obesity an inflammatory condition? Nutrition 2001, 17:953-966.

61. Schaffler A, Muller-Ladner U, Scholmerich J, Buchler C: Role of adipose tissue as an inflammatory organ in human diseases. Endocr Rev 2006, 27:449-467.

62. Xu H, Barnes GT, Yang Q, Tan G, Yang D, Chou CJ, Sole J, Nichols A, Ross JS, Tartaglia LA, Chen H: Chronic inflammation in fat plays a crucial role in the development of obesity-related insulin resistance. J Clin Invest 2003, 112:1821-1830.

63. Weisberg SP, McCann D, Desai M, Rosenbaum M, Leibel RL, Ferrante AW Jr: Obesity is associated with macrophage accumulation in adipose tissue. $J$ Clin Invest 2003, 112:1796-1808.

64. Neels JG, Olefsky JM: Inflamed fat: what starts the fire? J Clin Invest 2006, 116:33-35.

65. Curat CA, Miranville A, Sengenes C, Diehl M, Tonus C, Busse R, Bouloumie A: From blood monocytes to adipose tissue-resident macrophages: induction of diapedesis by human mature adipocytes. Diabetes 2004, 53:1285-1292.
66. Sartipy $\mathrm{P}$, Loskutoff DJ: Monocyte chemoattractant protein 1 in obesity and insulin resistance. Proc Natl Acad Sci USA 2003, 100:7265-7270.

67. Wellen KE, Hotamisligil GS: Obesity-induced inflammatory changes in adipose tissue. J Clin Invest 2003, 112:1785-1788.

68. Bassols J, Ortega FJ, Moreno-Navarrete JM, Peral B, Ricart W, FernandezReal JM: Study of the proinflammatory role of human differentiated omental adipocytes. J Cell Biochem 2009, 107:1107-1117.

69. Yamauchi T, Kamon J, Waki H, Terauchi Y, Kubota N, Hara K, Mori Y, Ide T, Murakami K, Tsuboyama-Kasaoka N, et al: The fat-derived hormone adiponectin reverses insulin resistance associated with both lipoatrophy and obesity. Nat Med 2001, 7:941-946.

70. Schaffler A, Scholmerich J, Buchler C: Mechanisms of Disease: adipocytokines and visceral adipose tissue[mdash]emerging role in intestinal and mesenteric diseases. Nat Clin Pract Gastroenterol Hepatol 2005, 2:103-111.

71. Dieudonne M-N, Bussiere M, Dos Santos E, Leneveu M-C, Giudicelli Y, Pecquery R: Adiponectin mediates antiproliferative and apoptotic responses in human MCF7 breast cancer cells. Biochemical and Biophysical Research Communications 2006, 345:271-279.

72. Brakenhielm E, Veitonmaki N, Cao R, Kihara S, Matsuzawa Y, Zhivotovsky B, Funahashi T, Cao Y: Adiponectin-induced antiangiogenesis and antitumor activity involve caspase-mediated endothelial cell apoptosis. Proc Natl Acad Sci USA 2004, 101:2476-2481.

73. Wang Y, Lam KSL, Xu A: Adiponectin as a negative regulator in obesityrelated mammary carcinogenesis. Cell Res 2007, 17:280-282.

74. Roberts $\mathrm{DL}$, Dive $\mathrm{C}$, Renehan AG: Biological mechanisms linking obesity and cancer risk: new perspectives. Annu Rev Med 2010, 61:301-316.

75. Renehan AG, Roberts DL, Dive C: Obesity and cancer: pathophysiological and biological mechanisms. Arch Physiol Biochem 2008, 114:71-83.

76. Kadowaki T, Yamauchi T: Adiponectin and adiponectin receptors. Endocr Rev 2005, 26:439-451.

77. Cummings DE, Foster KE: Ghrelin-leptin tango in body-weight regulation. Gastroenterology 2003, 124:1532-1535.

78. Howard JM, Beddy P, Ennis D, Keogan M, Pidgeon GP, Reynolds JV: Associations between leptin and adiponectin receptor upregulation, visceral obesity and tumour stage in oesophageal and junctional adenocarcinoma. British Journal of Surgery 97:1020-1027.

79. Jain SS, Bird RP: Elevated expression of tumor necrosis factor-alpha signaling molecules in colonic tumors of Zucker obese $(\mathrm{fa} / \mathrm{fa}$ ) rats. Int $\mathrm{J}$ Cancer 2010, 127:2042-2050.

80. Rodeheffer MS, Birsoy K, Friedman JM: Identification of White Adipocyte Progenitor Cells In Vivo. Cell 2008, 135:240-249.

81. Zhang Y, Daquinag A, Traktuev DO, Amaya-Manzanares F, Simmons PJ, March KL, Pasqualini R, Arap W, Kolonin MG: White adipose tissue cells are recruited by experimental tumors and promote cancer progression in mouse models. Cancer Res 2009, 69:5259-5266.

82. Coussens LM, Werb Z: Inflammation and cancer. Nature 2002, 420:860-867.

83. Guiu B, Petit JM, Bonnetain F, Ladoire S, Guiu S, Cercueil J-P, Krausé D, Hillon P, Borg C, Chauffert B, Ghiringhelli F: Visceral fat area is an independent predictive biomarker of outcome after first-line bevacizumab-based treatment in metastatic colorectal cancer. Gut 2010, 59:341-347.

84. Reeves GK, Pirie K, Beral V, Green J, Spencer E, Bull D: Cancer incidence and mortality in relation to body mass index in the Million Women Study: cohort study. BMJ 2007, 335:1134.

85. Moghaddam AA, Woodward M, Huxley R: Obesity and risk of colorectal cancer: a meta-analysis of 31 studies with 70,000 events. Cancer Epidemiol Biomarkers Prev 2007, 16:2533-2547.

86. Calle EE: Obesity and cancer. BMJ 2007, 335:1107-1108.

87. Derby CA, Zilber S, Brambilla D, Morales KH, McKinlay JB: Body mass index, waist circumference and waist to hip ratio and change in sex steroid hormones: the Massachusetts Male Ageing Study. Clin Endocrinol (Oxf) 2006, 65:125-131.

88. Hemsell DL, Grodin JM, Brenner PF, Siiteri PK, Macdonald PC: Plasma Precursors of Estrogen. II. Correlation of the Extent of Conversion of Plasma Androstenedione to Estrone with Age. J Clin Endocrinol Metab 1974, 38:476-479.

89. Kleinman D, Karas M, Danilenko M, Arbell A, Roberts CT, LeRoith D, Levy J, Sharoni $Y$ : Stimulation of endometrial cancer cell growth by tamoxifen is associated with increased insulin-like growth factor (IGF)-I induced 
tyrosine phosphorylation and reduction in IGF binding proteins. Endocrinology 1996, 137:1089-1095.

90. Slattery ML, Ballard-Barbash R, Edwards S, Caan BJ, Potter JD: Body mass index and colon cancer: an evaluation of the modifying effects of estrogen (United States). Cancer Causes Control 2003, 14:75-84.

91. Pan SY, Johnson KC, Ugnat AM, Wen SW, Mao Y: Association of obesity and cancer risk in Canada. Am J Epidemiol 2004, 159:259-268.

92. Wolk A, Gridley G, Svensson M, Nyren O, McLaughlin JK, Fraumeni JF, Adam HO: A prospective study of obesity and cancer risk (Sweden). Cancer Causes Control 2001, 12:13-21.

93. Calle EE, Kaaks R: Overweight, obesity and cancer: epidemiological evidence and proposed mechanisms. Nat Rev Cancer 2004, 4:579-591.

94. Key TJ, Appleby PN, Reeves GK, Roddam A, Dorgan JF, Longcope C, Stanczyk FZ, Stephenson HE Jr, Falk RT, Miller R, et al: Body mass index, serum sex hormones, and breast cancer risk in postmenopausal women. J Natl Cancer Inst 2003, 95:1218-1226.

95. Brochu M, Starling RD, Tchernof A, Matthews DE, Garcia-Rubi E, Poehlman ET: Visceral adipose tissue is an independent correlate of glucose disposal in older obese postmenopausal women. $J$ Clin Endocrinol Metab 2000, 85:2378-2384.

96. Fasshauer M, Paschke R: Regulation of adipocytokines and insulin resistance. Diabetologia 2003, 46:1594-1603.

97. Rajala MW, Scherer PE: Minireview: The adipocyte-at the crossroads of energy homeostasis, inflammation, and atherosclerosis. Endocrinology 2003, 144:3765-3773.

98. Greenberg AS, MCDaniel ML: Identifying the links between obesity, insulin resistance and beta-cell function: potential role of adipocyte-derived cytokines in the pathogenesis of type 2 diabetes. Eur J Clin Invest 2002, 32(Suppl 3):24-34.

99. LeRoith D: Beta-cell dysfunction and insulin resistance in type 2 diabetes: role of metabolic and genetic abnormalities. Am J Med 2002, 113(Suppl 6A):3S-11S.

100. Calle EE, Kaaks R: Overweight, obesity and cancer: epidemiological evidence and proposed mechanisms. Nat Rev Cancer 2004, 579-591.

101. Moller DE, Flier JS: Insulin resistance-mechanisms, syndromes, and implications. N Engl J Med 1991, 325:938-948.

102. Wajchenberg BL: Subcutaneous and Visceral Adipose Tissue: Their Relation to the MetabolicSyndrome. Endocr Rev 2000, 21:697-738.

103. Stocks T, Rapp K, Bjørge T, Manjer J, Ulmer H, Selmer R, Lukanova A, Johansen D, Concin H, Tretli S, et al: Blood Glucose and Risk of Incident and Fatal Cancer in the Metabolic Syndrome and Cancer Project (Me-Can): Analysis of Six Prospective Cohorts. PLoS Med 2009, 6:e1000201.

104. Rose DP, Komninou D, Stephenson GD: Obesity, adipocytokines, and insulin resistance in breast cancer. Obes Rev 2004, 5:153-165.

105. Giovannucci E: Metabolic syndrome, hyperinsulinemia, and colon cancer: a review. The American Journal of Clinical Nutrition 2007, 86:836S-842S

106. Hsing AW, Gao Y-T, Chua S, Deng J, Stanczyk FZ: Insulin Resistance and Prostate Cancer Risk. Journal of the National Cancer Institute 2003, 95:67-71.

107. Argiles JM, Lopez-Soriano FJ: Insulin and cancer (Review). Int J Oncol 2001, 18:683-687.

108. Pisani P: Hyper-insulinaemia and cancer, meta-analyses of epidemiological studies. Archives Of Physiology And Biochemistry 2008 114:63-70.

109. Nicolucci A: Epidemiological aspects of neoplasms in diabetes. Acta Diabetologica 2010, 47:87-95

110. Schoen RE, Tangen CM, Kuller LH, Burke GL, Cushman M, Tracy RP, Dobs A, Savage PJ: Increased blood glucose and insulin, body size, and incident colorectal cancer. J Natl Cancer Inst 1999, 91:1147-1154.

111. Ahmed RL, Schmitz KH, Anderson KE, Rosamond WD, Folsom AR: The metabolic syndrome and risk of incident colorectal cancer. Cancer 2006, 107:28-36.

112. Larsson SC, Giovannucci E, Wolk A: Diabetes and colorectal cancer incidence in the cohort of Swedish men. Diabetes Care 2005, 28:1805-1807.

113. Goodwin PJ, Ennis M, Pritchard Kl, Trudeau ME, Koo J, Hartwick W, Hoffman B, Hood N: Insulin-like growth factor binding proteins 1 and 3 and breast cancer outcomes. Breast Cancer Research and Treatment 2002, 74:65-76.
114. Amling CL, Riffenburgh RH, Sun L, Moul JW, Lance RS, Kusuda L, Sexton WJ, Soderdahl DW, Donahue TF, Foley JP, et al: Pathologic Variables and Recurrence Rates As Related to Obesity and Race in Men With Prostate Cancer Undergoing Radical Prostatectomy. Journal of Clinical Oncology 2004, 22:439-445.

115. Wolpin BM, Meyerhardt JA, Chan AT, Ng K, Chan JA, Wu K, Pollak MN, Giovannucci EL, Fuchs CS: Insulin, the Insulin-Like Growth Factor Axis, and Mortality in Patients With Nonmetastatic Colorectal Cancer. Journal of Clinical Oncology 2009, 27:176-185.

116. Yang YX, Hennessy S, Lewis JD: Insulin therapy and colorectal cancer risk among type 2 diabetes mellitus patients. Gastroenterology 2004, 127:1044-1050.

117. Osborne CK, Bolan G, Monaco ME, Lippman ME: Hormone responsive human breast cancer in long-term tissue culture: effect of insulin. Proc Natl Acad Sci USA 1976, 73:4536-4540

118. Pollak M: Insulin and insulin-like growth factor signalling in neoplasia. Nat Rev Cancer 2008, 8:915-928.

119. Samani AA, Yakar S, LeRoith D, Brodt P: The role of the IGF system in cancer growth and metastasis: overview and recent insights. Endocr Rev 2007, 28:20-47.

120. Frasca F, Pandini G, Sciacca L, Pezzino V, Squatrito S, Belfiore A, Vigneri R: The role of insulin receptors and IGF-I receptors in cancer and other diseases. Arch Physiol Biochem 2008, 114:23-37.

121. Jones $\mathrm{Jl}$, Clemmons DR: Insulin-like growth factors and their binding proteins: biological actions. Endocr Rev 1995, 16:3-34.

122. Schernhammer ES, Tworoger SS, Eliassen AH, Missmer SA, Holly JM, Pollak MN, Hankinson SE: Body shape throughout life and correlations with IGFs and GH. Endocr Relat Cancer 2007, 14:721-732.

123. Lukanova A, Soderberg S, Stattin P, Palmqvist R, Lundin E, Biessy C, Rinaldi S, Riboli E, Hallmans G, Kaaks R: Nonlinear relationship of insulinlike growth factor (IGF)-I and IGF-I/IGF-binding protein-3 ratio with indices of adiposity and plasma insulin concentrations (Sweden). Cancer Causes Control 2002, 13:509-516.

124. Gram IT, Norat T, Rinaldi S, Dossus L, Lukanova A, Tehard B, ClavelChapelon F, van Gils CH, van Noord PAH, Peeters PHM, et al: Body mass index, waist circumference and waist-hip ratio and serum levels of IGF-I and IGFBP-3 in European women. Int J Obes 2006, 30:1623-1631.

125. Ohlsson C, Mohan S, Sjogren K, Tivesten A, Isgaard J, Isaksson O, Jansson JO, Svensson J: The Role of Liver-Derived Insulin-Like Growth Factor-I. Endocr Rev 2009, 30:494-535.

126. Holzenberger M, Dupont J, Ducos B, Leneuve P, Geloen A, Even PC, Cervera P, Le Bouc Y: IGF-1 receptor regulates lifespan and resistance to oxidative stress in mice. Nature 2003, 421:182-187.

127. Sutherland BW, Knoblaugh SE, Kaplan-Lefko PJ, Wang F, Holzenberger M, Greenberg NM: Conditional Deletion of Insulin-like Growth Factor-I Receptor in Prostate Epithelium. Cancer Research 2008, 68:3495-3504.

128. Belfiore A, Frasca F, Pandini G, Sciacca L, Vigneri R: Insulin Receptor Isoforms and Insulin Receptor/Insulin-Like Growth Factor Receptor Hybrids in Physiology and Disease. Endocr Rev 2009, 30:586-623.

129. LeRoith $D$, Roberts $C T$ Jr: The insulin-like growth factor system and cancer. Cancer Lett 2003, 195:127-137.

130. Firth SM, Baxter RC: Cellular Actions of the Insulin-Like Growth Factor Binding Proteins. Endocr Rev 2002, 23:824-854.

131. Zhu W, Shiojima I, Ito Y, Li Z, Ikeda H, Yoshida M, Naito AT, Nishi J, Ueno H, Umezawa A, et al: IGFBP-4 is an inhibitor of canonical Wnt signalling required for cardiogenesis. Nature 2008, 454:345-349.

132. Pollak MN, Schernhammer ES, Hankinson SE: Insulin-like growth factors and neoplasia. Nat Rev Cancer 2004, 4:505-518.

133. Morgillo F, Woo JK, Kim ES, Hong WK, Lee HY: Heterodimerization of insulin-like growth factor receptor/epidermal growth factor receptor and induction of survivin expression counteract the antitumor action of erlotinib. Cancer Res 2006, 66:10100-10111.

134. Zong CS, Chan J, Levy DE, Horvath C, Sadowski HB, Wang LH: Mechanism of STAT3 activation by insulin-like growth factor I receptor. J Biol Chem 2000, 275:15099-15105.

135. Sell C, Rubini M, Rubin R, Liu JP, Efstratiadis A, Baserga R: Simian virus 40 large tumor antigen is unable to transform mouse embryonic fibroblasts lacking type 1 insulin-like growth factor receptor. Proc Natl Acad Sci USA 1993, 90:11217-11221. 
136. Hellawell GO, Turner GDH, Davies DR, Poulsom R, Brewster SF, Macaulay VM: Expression of the Type 1 Insulin-like Growth Factor Receptor Is Up-Regulated in Primary Prostate Cancer and Commonly Persists in Metastatic Disease. Cancer Research 2002, 62:2942-2950.

137. Law JH, Habibi G, Hu K, Masoudi H, Wang MYC, Stratford AL, Park E, Gee JMW, Finlay P, Jones HE, et al: Phosphorylated Insulin-Like Growth Factor-I/Insulin Receptor Is Present in All Breast Cancer Subtypes and Is Related to Poor Survival. Cancer Research 2008, 68:10238-10246.

138. Chan B, Lee A: Insulin Receptor Substrates (IRSs) and Breast Tumorigenesis. Journal of Mammary Gland Biology and Neoplasia 2008, 13:415-422.

139. Guvakova MA: Insulin-like growth factors control cell migration in health and disease. The International Journal of Biochemistry \& Cell Biology 2007, 39:890-909.

140. de Bono JS, Attard G, Adjei A, Pollak MN, Fong PC, Haluska P, Roberts L, Melvin C, Repollet M, Chianese D, et al: Potential Applications for Circulating Tumor Cells Expressing the Insulin-Like Growth Factor-I Receptor. Clinical Cancer Research 2007, 13:3611-3616.

141. Jones RA, Campbell Cl, Gunther EJ, Chodosh LA, Petrik JJ, Khokha R, Moorehead RA: Transgenic overexpression of IGF-IR disrupts mammary ductal morphogenesis and induces tumor formation. Oncogene 2006, 26:1636-1644.

142. Chan JM, Stampfer MJ, Giovannucci E, Gann PH, Ma J, Wilkinson P, Hennekens CH, Pollak M: Plasma Insulin-Like Growth Factor-I and Prostate Cancer Risk: A Prospective Study. Science 1998, 279:563-566.

143. Chan JM, Stampfer MJ, Ma J, Gann P, Gaziano JM, Pollak M, Giovannucci E: Insulin-Like Growth Factor-I (IGF-I) and IGF Binding Protein-3 as Predictors of Advanced-Stage Prostate Cancer. Journal of the National Cancer Institute 2002, 94:1099-1106.

144. Majeed N, Blouin M-J, Kaplan-Lefko PJ, Barry-Shaw J, Greenberg NM Gaudreau P, Bismar TA, Pollak M: A germ line mutation that delays prostate cancer progression and prolongs survival in a murine prostate cancer model. Oncogene 2005, 24:4736-4740.

145. Yang X-F, Beamer WG, Huynh H, Pollak M: Reduced Growth of Human Breast Cancer Xenografts in Hosts Homozygous for the lit Mutation. Cancer Research 1996, 56:1509-1511.

146. Pollak M, Blouin MJ, Zhang JC, Kopchick JJ: Reduced mammary gland carcinogenesis in transgenic mice expressing a growth hormone antagonist. $\mathrm{Br} J$ Cancer 2001, 85:428-430.

147. Wu Y, Cui K, Miyoshi K, Hennighausen L, Green JE, Setser J, LeRoith D, Yakar S: Reduced Circulating Insulin-like Growth Factor I Levels Delay the Onset of Chemically and Genetically Induced Mammary Tumors. Cancer Research 2003, 63:4384-4388.

148. Khandwala HM, McCutcheon IE, Flyvbjerg A, Friend KE: The effects of insulin-like growth factors on tumorigenesis and neoplastic growth. Endocr Rev 2000, 21:215-244.

149. Jenkins PJ: Cancers associated with acromegaly. Neuroendocrinology 2006, 83:218-223.

150. Shevah O, Laron Z: Patients with congenital deficiency of IGF-I seem protected from the development of malignancies: A preliminary report. Growth Hormone \& IGF Research 2007, 17:54-57.

151. Tibblin G, Eriksson M, Cnattingius S, Ekbom A: High Birthweight as a Predictor of Prostate Cancer Risk. Epidemiology 1995, 6:423-424.

152. Sandhu MS, Luben R, Day NE, Khaw K-T: Self-Reported Birth Weight and Subsequent Risk of Colorectal Cancer. Cancer Epidemiology Biomarkers \& Prevention 2002, 11:935-938.

153. McCormack VA, Silva IdS, De Stavola BL, Mohsen R, Leon DA, Lithell HO: Fetal growth and subsequent risk of breast cancer: results from long term follow up of Swedish cohort. BMJ 2003, 326:248.

154. Diorio C, Brisson J, Berube S, Pollak M: Genetic polymorphisms involved in insulin-like growth factor (IGF) pathway in relation to mammographic breast density and IGF levels. Cancer Epidemiol Biomarkers Prev 2008, 17:880-888.

155. Byrne C, Colditz GA, Willett WC, Speizer FE, Pollak M, Hankinson SE: Plasma Insulin-like Growth Factor (IGF) I, IGF-binding Protein 3, and Mammographic Density. Cancer Research 2000, 60:3744-3748.

156. Tamimi RM, Cox DG, Kraft P, Pollak MN, Haiman CA, Cheng I, Freedman ML, Hankinson SE, Hunter DJ, Colditz GA: Common genetic variation in IGF1,
IGFBP-1, and IGFBP-3 in relation to mammographic density: a crosssectional study. Breast Cancer Res 2007, 9:R18.

157. Ma J, Pollak MN, Giovannucci E, Chan JM, Tao Y, Hennekens CH, Stampfer MJ: Prospective Study of Colorectal Cancer Risk in Men and Plasma Levels of Insulin-Like Growth Factor (IGF)-I and IGF-Binding Protein-3. Journal of the National Cancer Institute 1999, 91:620-625.

158. Giovannucci E, Pollak MN, Platz EA, Willett WC, Stampfer MJ, Majeed N, Colditz GA, Speizer FE, Hankinson SE: A Prospective Study of Plasma Insulin-like Growth Factor-1 and Binding Protein-3 and Risk of Colorectal Neoplasia in Women. Cancer Epidemiology Biomarkers \& Prevention 2000, 9:345-349.

159. Palmqvist R, Hallmans G, Rinaldi S, Biessy C, Stenling R, Riboli E, Kaaks R: Plasma insulin-like growth factor 1, insulin-like growth factor binding protein 3, and risk of colorectal cancer: a prospective study in northern Sweden. Gut 2002, 50:642-646.

160. Harman SM, Metter EJ, Blackman MR, Landis PK, Carter HB: Serum Levels of Insulin-Like Growth Factor I (IGF-I), IGF-II, IGF-Binding Protein-3, and Prostate-Specific Antigen as Predictors of Clinical Prostate Cancer. J Clin Endocrinol Metab 2000, 85:4258-4265.

161. Stattin P, Bylund A, Rinaldi S, Biessy C, Déchaud H, Stenman U-H, Egevad L, Riboli E, Hallmans G, Kaaks R: Plasma Insulin-Like Growth Factor-I, InsulinLike Growth Factor-Binding Proteins, and Prostate Cancer Risk: a Prospective Study. Journal of the National Cancer Institute 2000 92:1910-1917.

162. de Graaff LCG, Argente J, van Meurs JBJ, Uitterlinden AG, HokkenKoelega ACS: Genetic Polymorphisms in the Locus Control Region and Promoter of GH1 Are Related to Serum IGF-I Levels and Height in Patients with Isolated Growth Hormone Deficiency and Healthy Controls. Hormone Research in Paediatrics 2010, 73:25-34.

163. Gu F, Schumacher FR, Canzian F, Allen NE, Albanes D, Berg CD, Berndt SI, Boeing $\mathrm{H}$, Bueno-de-Mesquita HB, Buring JE, et al: Eighteen Insulin-like Growth Factor Pathway Genes, Circulating Levels of IGF-I and Its Binding Protein, and Risk of Prostate and Breast Cancer. Cancer Epidemiology Biomarkers \& Prevention 2010, 19:2877-2887.

164. Wong H-L, DeLellis K, Probst-Hensch N, Koh W-P, Van Den Berg D, Lee H-P, Yu MC, Ingles SA: A New Single Nucleotide Polymorphism in the InsulinLike Growth Factor I Regulatory Region Associates with Colorectal Cancer Risk in Singapore Chinese. Cancer Epidemiology Biomarkers \& Prevention 2005, 14:144-151.

165. McElholm AR, McKnight AJ, Patterson CC, Johnston BT, Hardie LJ, Murray LJ: A population-based study of IGF axis polymorphisms and the esophageal inflammation, metaplasia, adenocarcinoma sequence. Gastroenterology 2010, 139:204-212 e203.

166. Terry KL, Tworoger SS, Gates MA, Cramer DW, Hankinson SE: Common genetic variation in IGF1, IGFBP1 and IGFBP3 and ovarian cancer risk. Carcinogenesis 2009, 30:2042-2046.

167. Zhang M, Hu Z, Huang J, Shu Y, Dai J, Jin G, Tang R, Dong J, Chen Y, Xu L, et al: A 3'-Untranslated Region Polymorphism in IGF1 Predicts Survival of Non-Small Cell Lung Cancer in a Chinese Population. Clinical Cancer Research 2010, 16:1236-1244.

168. Schumacher FR, Cheng I, Freedman ML, Mucci L, Allen NE, Pollak MN, Hayes RB, Stram DO, Canzian F, Henderson BE, et al: A comprehensive analysis of common IGF1, IGFBP1 and IGFBP3 genetic variation with prospective IGF-I and IGFBP-3 blood levels and prostate cancer risk among Caucasians. Human Molecular Genetics 2010, 19:3089-3101.

169. Suga K, Imai K, Eguchi H, Hayashi S, Higashi Y, Nakachi K: Molecular significance of excess body weight in postmenopausal breast cancer patients, in relation to expression of insulin-like growth factor I receptor and insulin-like growth factor II genes. Cancer Science 2001, 92:127-134.

170. Papaxoinis K, Patsouris E, Kittas C, Nicolopoulou-Stamati P: Insulinlike growth factor I receptor and estrogen receptor [beta] expressions are inversely correlated in colorectal neoplasms and affected by the insulin resistance syndrome. Human Pathology 2007, 38:1037-1046.

171. Frystyk J: Free insulin-like growth factors - measurements and relationships to growth hormone secretion and glucose homeostasis. Growth Hormone \& IGF Research 2004, 14:337-375.

172. Heemskerk VH, Daemen MARC, Buurman WA: Insulin-like growth factor-1 (IGF-1) and growth hormone (GH) in immunity and inflammation. Cytokine \& Growth Factor Reviews 1999, 10:5-14. 
173. Renier G, Clement I, Desfaits AC, Lambert A: Direct stimulatory effect of insulin-like growth factor-I on monocyte and macrophage tumor necrosis factor-alpha production. Endocrinology 1996, 137:4611-4618.

174. Wu Y, Brodt P, Sun H, Mejia W, Novosyadlyy R, Nunez N, Chen X,

Mendoza A, Hong S-H, Khanna C, Yakar S: Insulin-Like Growth Factor-I Regulates the Liver Microenvironment in Obese Mice and Promotes Liver Metastasis. Cancer Research 2010, 70:57-67.

doi:10.1186/1758-5996-3-12

Cite this article as: Donohoe et al.: Visceral adiposity, insulin resistance and cancer risk. Diabetology \& Metabolic Syndrome 2011 3:12.

Submit your next manuscript to BioMed Central and take full advantage of:

- Convenient online submission

- Thorough peer review

- No space constraints or color figure charges

- Immediate publication on acceptance

- Inclusion in PubMed, CAS, Scopus and Google Scholar

- Research which is freely available for redistribution

Submit your manuscript at www.biomedcentral.com/submit 